Jurnal Ilmu-Ilmu Peternakan 25 (3): 69 - 79

ISSN: 0852-3681

E-ISSN: 2443-0765

CFakultas Peternakan UB, http://jiip.ub.ac.id/

\title{
Pengaruh pengencer Tris Aminomethane kuning telur yang disuplementasi sari kulit Manggis (Garcinia Mangostana) terhadap kualitas semen Sapi Limousin selama penyimpanan suhu dingin $5^{\circ} \mathrm{C}$
}

\author{
Fredyan Isnan Effendi, Sri Wahjuningsih dan M. Nur Ihsan \\ Fakultas Peternakan, Universitas Brawijaya, Malang \\ Jl. Veteran Malang 65145 Jawa Timur \\ effendifredy059@gmail.com
}

\begin{abstract}
The purpose of this research was to determine thedoseof mangosteen rindsjuice $(0 \%, 2 \%$, and $4 \%)$ ina diluent Tris Aminomethane-egg yolk. The freshsemenwas collected once a weekusingan artificialvagina from five Limousin bulls aged 8 to 11 years old with a body weight of $895-1034 \mathrm{~kg}$. The research method was experimental laboratory using a randomized block design with 3 treatments and 10 replications.If there were significant influencesamong the variables, it would be then tested by Duncan's Multiple Range test method. The result showed that Tris Aminomethane-egg yolkdiluentwith4\% of mangosteen rindsjuicesuplementationhad significant differences $(\mathrm{P}<0.05)$ on the sperm quality kept for 72 hours in the cold storage in terms of the percentage ofsperm motility and sperm viability.It alsohada significant difference $(\mathrm{P}<0.05)$ on sperm abnormality particularly within the $1^{\text {st }}$ hour. It can be concluded that the addition of $4 \%$ mangosteen rindsjuiceinTris Aminomethaneegg yolk diluentcouldprotectLimousin bull semen quality (motility, viabilityand abnormality) after stored for 72 hours at $5^{0} \mathrm{C}$.
\end{abstract}

Keywords: Abnormality, liquid semen, mangosteen rind, motility, viability

\section{PENDAHULUAN}

Salah satu cara untuk meningkatkan kualitas sapi lokal adalah dengan memanfaatkan teknologi Inseminasi Buatan (IB) menggunakan sapi yang mempunyai kualitas genetik unggul seperti memiliki penampilan kekar, berotot, dada yang besar, berdaging, memiliki pertumbuhan yang bagus, tubuh besar dan panjang. Sapi Limousin termasuk ternak potong berkualitas baik dan memiliki genetik unggul, bentuk tubuhnya panjang dan tingkat pertumbuhannya tinggi.

Keberhasilan IB baik menggunakan semen cair maupun beku membutuhkan semen yang berkualitas baik dengan daya hidup tinggi, sehingga memerlukan proses pengenceran semen yang efektif, efisien dan murah. Penggunaan semen segar yang diencerkan terbukti menghasilkan fertilitas tinggi dengan biaya lebih murah (Susilawati, dkk., 2008). Pengenceran semen bertujuan untuk mendapatkan jumlah semen yang lebih banyak sebelum diinseminasikan dan mempertahankan kualitas semen sebelum disemprotkan kedalam alat reproduksi betina. Pengenceran semen tergantung pada volume semen, konsentrasi semen, persentase 
spermatozoa hidup dan bergerak progresif serta dosis semen untuk diinseminasikan (Ax, et al., 2008).

Syarat penting yang harus dimiliki oleh setiap pengencer menurut Susilawati (2011) adalah: (1) bahan tidak bersifat toksik terhadap spermatozoa, (2) mengandung sumber energi, (3) bersifat isotonis, (4) mengandung buffer, (5) melindungi dari pengaruh pendinginan secara cepat, (6) menghambat pertumbuhan bakteri,(7) dan meningkatkan volume sehingga bisa digunakan beberapa kali IB. Salah satu pengencer yang banyak digunakan dan terbukti mampu mempertahankan kualitas semen cair adalah pengencer Tris Aminomethane kuning telur.

Semen akan mengalami proses metabolisme selama penyimpanan pada suhu ruang maupun dingin. Metabolisme semen menghasilkan salah satunya reaksi peroksidatif lipid jika bereaksi dengan radikal bebas (Zaniboni, et al., 2006). Radikal bebas yang terdapat pada spermatozoa ditandai dengan meningkatnya Reactive Oxygen Species (ROS) (Sikka, 2004). Susilawati dkk. (2008) menjelaskan bahwa produksi ROS yang berlebihan tidak mampu dinetralisir oleh sistem pertahanan, sehingga antioksidan pada spermatozoa atau plasma seminalis dapat menyebabkan kerusakan asam lemak, khususnya asam lemak poli tak jenuh yang disebut lipid peroksidase. Lipid peroksidase merupakan komponen penting dari fosfolipid penyusun membran spermatozoa yang menyebabkan penurunan motilitas dan kematian spermatozoa. Terbentuknya radikal peroksida lipid dapat ditekan oleh antioksidan (Suyadi, dkk., 2012).

Antioksidan yang dapat digunakan adalah xanthoneyang terdapat pada kulit manggis untuk penyeimbang prooxidant (reducing radicalsand oxidicing radicals) dan anti bakteri sehingga mampu mempertahankan kualitas semen sapi Limousinsecara signifikan. Jung, et al. (2006) menjelaskan bahwa buah manggis (Garcinia mangostana L.) juga diduga berpotensi sebagai antioksidan alami.Beberapa penelitian in vitro telah menunjukkan bahwa sari kulit manggis (SKM) mempunyai kemampuan sebagai antioksidan. Di antara senyawa xanthone, alfa-mangostein merupakan komponen terbesar serta memiliki kemampuan sebagai antioksidan kuat. Penelitian ini bertujuan untuk mengetahui pengaruh penambahan bahan pengencer Tris Aminomethane kuning telur yang menggunakan antioksidan berbahan baku kulit manggis terhadap kualitassemen Sapi Limousin.

\section{MATERI DAN METODE}

\section{Materi penelitian}

Materi penelitian yang digunakan adalah semen segar afkir dari lima ekor sapi Limousin dewasa dengan kisaran bobot badan 895-1034 kg berumur 6-11 tahun.

\section{Metode penelitian}

Metode penelitian yang digunakan adalah percobaan laboratorium (experimental laboratory). Semen segar sapi Limousin yang baru diambil dari penampungan dilakukan uji makroskopis meliputi volume, warna, bau, konsistensi dan $\mathrm{pH}$. Sedangkan uji mikroskopis meliputi motilitas individu, motilitas massa, konsentrasi spermatozoa, viabilitas dan abnormalitas. Semen segar dimasukkan kedalam tabung perlakuan P0, P1, P2 dan diencerkan dengan Tris Aminomethane kuning telur yang ditambah SKM. Tiga perlakuan penambahan SKM yaitu $\mathrm{P}_{0} \quad(0 \%$ $\mathrm{SKM}+100 \%$ Tris Aminomethane KT), 
$\mathrm{P}_{1}$ (2\% SKM+98\%Tris Aminomethane KT), dan $\mathrm{P}_{2} \quad(4 \% \quad \mathrm{SKM}+96 \%$ Tris Aminomethane KT) dan dilakukan ulangan sebanyak 10 kali dengan lama penyimpanan pada suhu dingin $5^{\circ} \mathrm{C}$.

\section{Pembuatan SKM}

Proses pembuatan SKM

dilakukan melalui prosedur antara lain:Pencucian kulit buah manggis kering sebanyak 250 gram menggunakan air hangat pada suhu $45^{\circ} \mathrm{C}$, lalu kulit manggis dan aquabidest diblender dengan perbandingan 1:4 (kulit manggis:aquabidest). Supernatan yang dihasilkan disaring menggunakan kain saring.Sari kulit manggis kemudian disentrifugasi selama 30 menit dengan kecepatan $1500 \mathrm{rpm}$ dan dipisahkan dari residu. Sentrifugasi tahap kedua dengan waktu dan kecepatan yang sama. Larutan dan residunya dipisahkan menggunakan kain saring, selanjutnya dilakukan inaktivasi dalam oven bersuhu $56^{\circ} \mathrm{C}$ selama 30 menit dan disimpan pada suhu dingin dalam refrigerator (dimodifikasi dari Chaovanalikit, et al., 2012 dan Caridi, et al., 2007).

\section{Penambahan SKM dalam pengencer Tris Aminomethane kuning telur}

Semen yang digunakan dalam penelitian ini adalah semen afkir yang tidak lolos untuk dilakukan proses lebih lanjut oleh BBIB (motilitas individu $\leq$ $70 \%$ ) dan memiliki motilitas massa minimal 2+.Kuning telur yang digunakan adalah kuning telur ayam ras berumur maksimal empat hari sesuai hasil penelitian Wiratri, dkk., (2014). Setelah evaluasi terhadap kualitas semen segar, semen dibagi dalam tiga kelompok perlakuan pengencer Tris Aminomethane kuning telur yang telah ditambah SKM sesuai perlakuan masing-masing dengan perbandingan semen:pengencer adalah 1:1.

\section{Penampungan semen}

Penampungan semen sapi Limousin dilakukansatu kali dalam seminggu menggunakan vagina buatan yang dipancing dengan teaser bull. Vagina buatan disiapkan dengan memasang kedua selubung karet atau inner liner dan alat penampung yang telah steril, sedangkan ruangan antara selubung luar dan dalam diisi air hangat bersuhu $45^{\circ} \mathrm{C}$.Lalu vagina buatan yang telah diolesi dengan lubricating jelly dibawa oleh seorang semen kolektor menggunakan tangan kanan dengan sudut kemiringan $\pm 35^{\circ}$. Petugas lain bertindak mengatasi tingkah laku ternak.Pertama-tama sapi Limousin jantan yang akan diambil semennya didekatkan ke teaser bull danpejantan dibiarkan menaiki teaser bullsebanyakkurang lebih tiga kali untuk memancing libido.Kemudian saat pejantan menaiki yang keempat kali, semen segar ditampung menggunakan vagina buatan kemudian dievaluasi secara makroskopis dan mikroskopis.

\section{Evaluasi semen segar}

Proses pemeriksaan semen harus dilakukan dengan cepat untuk menghindari dan meminimalisir kerusakan, kematian dan kehabisan energi bagi spermatozoa. Pemeriksaan semen yang dilakukan yaitu pemeriksaan makroskopis dan mikroskopis. Pemeriksaan makroskopis meliputi volume, warna, bau, $\mathrm{pH}$ dan konsistensi semen sedangkan pemeriksaan mikroskopis meliputi konsentrasi, motilitas massa dan persentase motilitas individu, viabilitas dan abnormalitas spermatozoa.

\section{Pendinginan}

Penyimpanan semen di lemari es pada suhu $5^{\circ} \mathrm{C}$ dapat dilakukan dengan metode water jacketyaitu penambahan air dengan suhu $30^{\circ} \mathrm{C}$ pada beaker 
gelassebagai tempat menaruh tabung reaksi yang berisi semen sesudah diencerkan. Semen yang telah berisi campuran pengencer Tris Aminomethane kuning telur dan SKM (sesuai perlakuan) diamati setiap jam penyimpanan dengan suhu refrigerator $5^{0}$ Cselama jam ke- 1, 2, 3, 24, 48 dan 72. Setiap jam penyimpanan dilakukan kembali uji kualitas secara mikroskopis meliputi motilitas individu, viabilitas dan abnormalitas di bawah mikroskop dengan perbesaran 400x.

\section{Analisa data}

Data yang diperoleh dianalisis menggunakan Analisis Ragam/ Analysis Of Variance (ANOVA) dalam Rancangan Acak Kelompok
(Randomized Block Design) dengan 10 kali ulangan dengan 3 perlakuan yang dikelompokkan berdasarkan waktu penampungan semen.Apabila terdapat perbedaan yang nyata maupun sangat nyata akan dilanjutkan dengan Uji Jarak Berganda Duncan (UJBD).

\section{HASIL DAN PEMBAHASAN}

\section{Pemeriksaan semen segar Sapi Limousin}

Sebelum dilakukan pengenceran, kualitas semen dievaluasi melaluiuji makroskopisdanmikroskopis.Hasil

pengamatan semen segar setelah penampungan selama penelitian dapat dilihat pada Tabel 1.

Tabel 1. Rataan semen segar Sapi Limousin

\begin{tabular}{lc}
\hline Variabel & Rataan \\
\hline Umur (tahun) & $8,6 \pm 1,51$ \\
Makroskopis & \\
Volume (ml) & $6,62 \pm 1,17$ \\
Warna & Putih susu \\
pH & $6,44 \pm 0,14$ \\
Konsistensi & Sedang \\
& \\
Mikroskopis & \\
Motilitas massa & $2+$ \\
Persentase motilitas individu (\%) & $49 \pm 5,68$ \\
Persentas viabilitas (\%) & $83,64 \pm 7,85$ \\
Persentase abnormalitas (\%) & $12,06 \pm 5,45$ \\
Konsentrasi (juta/ml) & $1120,4 \pm 197,9$ \\
\hline
\end{tabular}

Hasil penelitian menunjukkan rataan volume semen segar sapi Limousin adalah 6,62 $\pm 1,17 \mathrm{ml} /$ ejakulasi atau lebih rendah jika dibandingkan dengan volume semen segar sapi Limousin yang diteliti oleh Wiratri dkk. (2014) yakni 6,75 $\pm 0,68$ ml/ejakulasi.Rendahnya volume semen segar dipengaruhi oleh umur sapi Limousin yang digunakan saat penelitian. Wahjuningsih, dkk. (2013) menambahkan bahwa umur sapi pejantan merupakan salah satu faktor yang mempengaruhi kualitas semen, karena perkembangan testis dan spermatogenesis dipengaruhi oleh umur.

Konsistensi semen hasil penelitian termasuk kategori sedang dan berwarna putih susu. Suyadi dkk. 
(2012) menjelaskan bahwa warna, konsistensi dan konsentrasi spermatozoa mempunyai hubungan yang sangat erat satu dengan yang lain, artinya jika semen semakin encer maka konsentrasi spermatozoa semakin rendah dan warnanya semakin pucat. Ismaya (2014) menjelaskan bahwa konsistensi spermatozoa juga berkaitan dengan warna spermatozoa yang dapat digunakan untuk memprediksi konsentrasi spermatozoa.Ketika konsistensinya sedang hingga kental atau warna krem maka konsentrasi spermatozoa berkisar 1.000-2.000 juta spermatozoa/ml dan hal ini terbukti konsentrasi semen segar dalam penelitian ini sebanyak $1120,4 \pm 197,9$ juta/ml.

Konsentrasi adalah derajat kekentalan yang erat kaitannya dengan konsentrasi spermatozoa. Menurut Brito, et al.(2002), konsentrasi spermatozoa pada Bos taurus sebesar $1200 \mathrm{juta} / \mathrm{ml}$ dan $93,33 \%$ rata-rata pejantan memiliki konsentrasi lebih dari $1000 \mathrm{juta} / \mathrm{ml}$ dan $6,67 \%$ lainnya memiliki rata-rata konsentrasi kurang dari 1000 juta/ml.Namun nilai tersebut masih relatif normal, karena konsentrasi spermatozoa pada sapi berkisar 1000$1800 \mathrm{juta} / \mathrm{ml}$ (Susilawati, 2011).

Motilitas massa semen segar afkir sapi Limousin pada saat penelitian sebesar 2+. Susilawati (2011) menjelaskan bahwa penilaian motilitas massa dapat dikatakan baik (++) bila terlihat gelombang-gelombang kecil tipis, jarang, kurang jelas dan bergerak lamban, sehingga semen yang digunakan dalam penelitian ini masih bisa dikatakan layak untuk dilakukan proses lebih lanjut.

Hasil dari pemeriksaan mikroskopis menunjukkan bahwa rataan persentase motilitas individu semen afkir sapi Limousin adalah 49 $\pm 5,68 \%$ atau lebih rendah jika dibandingkan dengan rataan motilitas individu sapi Limousin hasil penelitian Wiratri dkk. (2014) yaitu $69,9 \pm 6,67 \%$ dan mempunyai motilitas massa sangat baik $(+++)$. Rendahnya motilitas individu hasil penelitian ini diduga karena faktor umur sapi dan semen segar tergolong afkir $100 \%$. Motilitas individu spermatozoa diamati menggunakan mikroskop dengan melihat pada pergerakkan progresif atau gerakan aktif maju ke depan. Gerakan melingkar atau gerakan mundur merupakan tanda cold shock atau media yang kurang isotonik terhadap semen.

Viabilitas merupakan salah satu indikator penentu kualitas semen karena berhubungan dengan daya hidup spermatozoa. Persentase viabilitas semen segar sapi Limousin hasil penelitian sebesar $83,64 \pm 7,85 \%$ atautermasuk kategori sangat baik karena persentase viabilitas $>70 \%$ atau persentase viabilitas harus diatas persentase motilitas. Lopes (2002) menjelaskan bahwa viabilitas semen masih dianggap baik jika memiliki kisaran nilai antara 50-69\%. Nugroho, dkk.(2015) menjelaskan bahwa rata-rata viabilitas spermatozoa pada semen segar adalah 83,09 $\pm 2,22 \%$.

Spermatozoa yang hidup dan mati dapat dibedakan reaksinya terhadap warna bahan pewarna eosin negrosin (Susilawati, 2011).Sel spermatozoa yang tidak motil dan dianggap mati menghisap warna dan sel spermatozoa yang motil dan yang hidup tidak berwarna. Perbedaan antara spermatozoa yang hidup dan yang mati dapat dilihat pada Gambar 1 . 


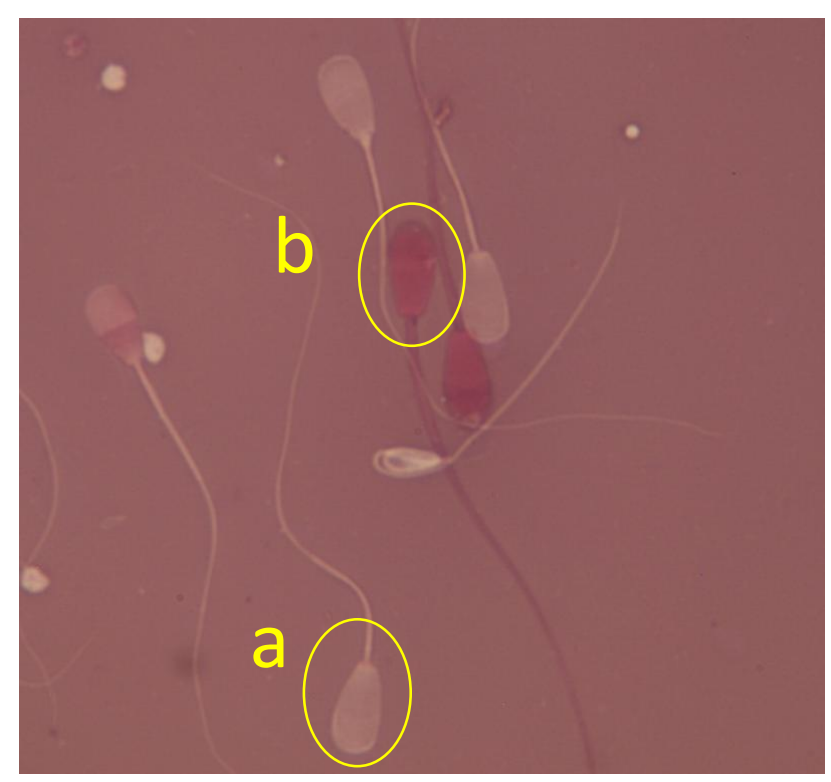

Gambar 1. Viabilitas spermatozoa diamati melalui mikroskop binokuler dengan perbesaran 1000x. Keterangan $a=$ spermatozoa hidup (tidak menyerap warna), $\mathrm{b}=$ spermatozoa mati (menyerap warna)

Persentase abnormalitas abnormalitas semen segar sapi spermatozoa semen segar sapi Limousin Limousin yang masih tergolong baik saat pengamatan rata-rata sebesar adalah 5-15\%. Perbedaan antara $12,06 \pm 5,45 \%$. Nugroho dkk (2015) spermatozoa normal dan spermatozoa menyebutkan bahwa ratan nilai abnormal dapat dilihat pada Gambar 2.

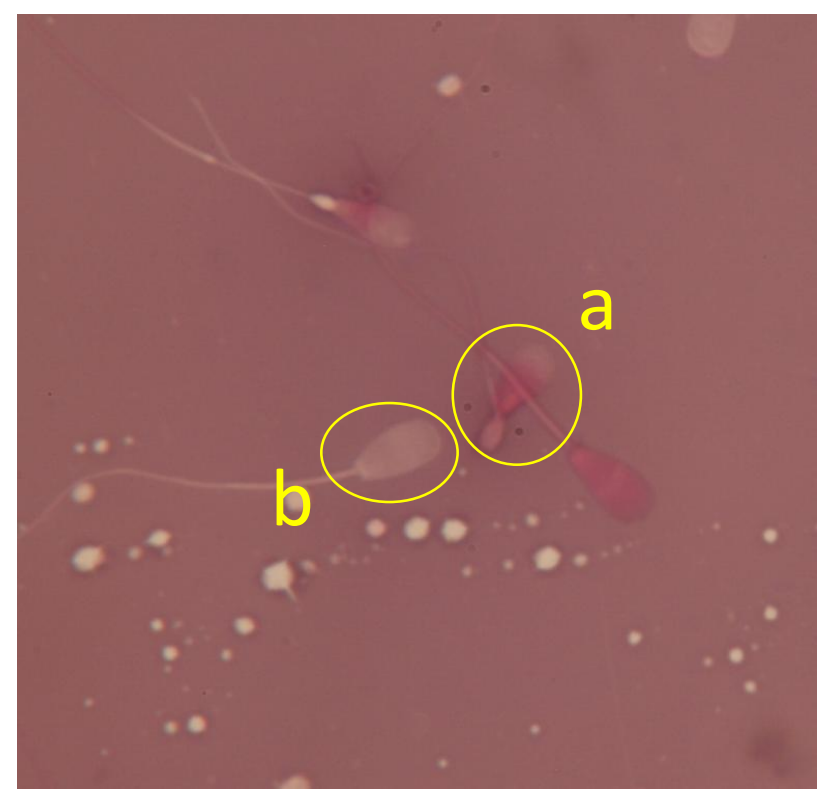

Gambar 2. Abnormalitas spermatozoa diamati melalui mikroskop binokuler dengan perbesaran 1000x. Keterangan gambar: $a=$ spermatozoa abnormal pada ekor yang melengkung, $\mathrm{b}=$ spermatozoa normal. 
Derajat keasaman atau $\mathrm{pH}$ perlu diketahui untuk memastikan bahwa cairan semen hasil penampungan memiliki karakter normal. $\mathrm{pH}$ semen hasil penelitian diperoleh rata-rata 6,44 $\pm 0,14$. Susilawati (2011) menyatakan bahwa rata-rata $\mathrm{pH}$ semen berkisar 6,2-6,8, sedangkan kisaran $\mathrm{pH}$ semen sapi pejantan menurut Garner and Hafez (2008) sebesar 6,4-7,8.

\section{Persentase motilitas individu spermatozoadengan penambahan SKM}

Salah satu faktor yang mempengaruhi fertilitas spermatozoa adalah motilitas indvidu spermatozoa yang merupakan salah satu indikator penting untuk penentuan kualitas semen secara umum. Hasil pengamatan rataan persentase motilitas individu spermatozoa dapat dilihat pada Tabel 2 .

Tabel 2. Nilai rataan motilitas individu spermatozoa sapi Limousin terhadap perlakuan

\begin{tabular}{cccc}
\hline Jam ke- & P0 (0\%) & P1 (2\%) & P2 (4\%) \\
\hline 1 & $48,5 \pm 4,74$ & $47 \pm 3,5$ & $49 \pm 4,59$ \\
2 & $43 \pm 5,87^{\mathrm{a}}$ & $44,5 \pm 4,97^{\mathrm{ab}}$ & $46 \pm 3,94^{\mathrm{b}}$ \\
3 & $38,5 \pm 5,3^{\mathrm{a}}$ & $41 \pm 5,68^{\mathrm{ab}}$ & $43,5 \pm 3,37^{\mathrm{b}}$ \\
24 & $33 \pm 4,22^{\mathrm{a}}$ & $34,5 \pm 4,38^{\mathrm{a}}$ & $38,5 \pm 3,37^{\mathrm{b}}$ \\
48 & $25,5 \pm 3,69^{\mathrm{a}}$ & $29,5 \pm 3,69^{\mathrm{b}}$ & $31,5 \pm 4,12^{\mathrm{c}}$ \\
72 & $19 \pm 3,16^{\mathrm{a}}$ & $20,5 \pm 2,84^{\mathrm{a}}$ & $23,5 \pm 3,37^{\mathrm{b}}$ \\
\hline
\end{tabular}

Keterangan : Notasi yang berbeda pada baris yang sama menunjukkan berbeda nyata $(\mathrm{P}<0,05)$

Tabel 2 menunjukkan bahwa perlakuan P2 yaitu Tris Aminomethane kuning telur+4\% SKM secara nyata $(\mathrm{P}<0,05)$ lebih tinggi dibandingkan dengan P0 dan P1 dalam mempertahankan motilitas individu spermatozoa setelah diencerkan dan disimpan pada suhu dingin selama 72 jam dibandingkan penambahan SKM lainnya. Pada penyimpanan jam ke-72 dapat dilihat bahwa persentase motilitas pada perlakuan dengan konsentrasi SKM 4\% adalah sebesar $(23,5 \pm 3,37 \%)$ atau lebih besar daripada perlakuan dengan penambahan konsentrasi SKM $0 \%$ dan SKM 2\%, yaitu berturut-turut adalah SKM 0\% $(19 \pm 3,16 \%)$ dan SKM $2 \%(20,5 \pm 2,84 \%)$. Penambahan SKM sebesar $4 \%$ mampu mempertahankan motilitas individu spermatozoa secara konsisten setelah pengenceran artinya kemampuan Tris Aminomethane kuning telur $+4 \%$ SKM mampu memberikan nutrisi bagi metabolisme spermatozoa dan melindungi lebih lamadari pengencer perlakuan lainnya karena memiliki daya preservasi paling baik. Arsana (2014) menjelaskan bahwaxanthone sebagai antioksidan mampu menangkal atau meredam dampak negatif oksidan dalam tubuh akibat paparan suhu dingin dengan cara mendonorkan satu elektronnya kepada senyawa yang bersifat oksidan sehingga aktivitasnya bisa dihambat dan meningkatkan motilitas spermatozoa. SKM yang digunakan dalam penelitian ini mengandung xanthone sebagai antioksidan yang tinggi sehingga dapat menstabilkan radikal bebas, memperbaiki komunikasi antar sel dan dapat meningkatkan motilitas spermatozoa walaupun diberi paparan suhu dingin. Sedangkan persentase motilitas pada jam ke-1 menunjukkan tidak ada perbedaan yang nyata $(\mathrm{P}>0,05)$ antara $\mathrm{P} 0, \mathrm{P} 1$ dan $\mathrm{P} 2$ meskipun motilitas individu P0 lebih besar jika dibandingkan dengan P1 namun lebih rendah dari P2 
karenawaktu penyesuaian diri yang kurang dari 1 jam.

\section{Persentase viabilitas spermatozoa dengan penambahan SKM}

Viabilitas

spermatozoa

tergantung pada keutuhan membran spermatozoa dan kerusakan membran spermatozoa akan menyebabkan terganggunya proses metabolisme intraseluler spermatozoa sehingga spermatozoa akan melemah dan bahkan bisa menyebabkan kematian (Ihsan, 2008). Hasil pengamatan rataan viabilitas spermatozoa dapat dilihat pada Tabel 3.

Tabel 3. Nilai rataan viabilitas spermatozoa sapi Limousin terhadap perlakuan

\begin{tabular}{cccc}
\hline Jam ke- & P0 (0\%) & P1 (2\%) & P2 (4\%) \\
\hline 1 & $68,96 \pm 8,7$ & $69,86 \pm 11,7$ & $74,42 \pm 8,8$ \\
2 & $63,11 \pm 8,9$ & $66,66 \pm 11,1$ & $67,37 \pm 8,6$ \\
3 & $58,57 \pm 10,9^{\mathrm{a}}$ & $63,7 \pm 7,1^{\mathrm{a}}$ & $65,02 \pm 7,8^{\mathrm{b}}$ \\
24 & $53,59 \pm 8,6^{\mathrm{a}}$ & $62,04 \pm 4,8^{\mathrm{b}}$ & $64,99 \pm 3,1^{\mathrm{c}}$ \\
48 & $45,15 \pm 11,6^{\mathrm{a}}$ & $47,62 \pm 12,01^{\mathrm{a}}$ & $56,73 \pm 7,5^{\mathrm{b}}$ \\
72 & $22.62 \pm 4,53^{\mathrm{a}}$ & $24,69 \pm 4,5^{\mathrm{a}}$ & $33,59 \pm 5,6^{\mathrm{b}}$ \\
\hline
\end{tabular}

Keterangan : Notasi yang berbeda pada baris yang sama menunjukkan berbeda nyata $(\mathrm{P}<0,05)$

Hasil analisis statistik pada Tabel 3 menunjukkan nilai viabilitas tidak mengalami perbedaan yang nyata $(\mathrm{P}>0,05)$ mulai dari jam ke-1 hingga jam ke-2.Hal ini dikarenakan waktu penyesuaian spermatozoa terhadap pengencer yang baru ditambahkan kurang dari 2 jam dan belum adanya penurunan temperatur yang drastis (dari suhu normal ke suhu refrigerator yaitu $4-5^{\circ} \mathrm{C}$ ) sehingga efek perlindungan belum terlihat. Hasil ini sama dengan penelitian Zega, dkk. (2015) yang menunjukkan bahwa pengencer kuning telur $15 \%$ mampu mempertahankan persentase viabilitas spermatozoa sapi Limousin yang terbaik saat mencapai penyimpanan pada suhu $5^{\circ} \mathrm{C}$.

Hasil analisis statistik menunjukkan nilai viabilitas berbeda nyata $(\mathrm{P}<0,05)$ mulai dari jam ke-3 hingga jam ke-72, artinya Tris Aminomethane kuning telur $+4 \%$ SKM memberikan perbedaan viabilitas yang meningkat atau lebih tinggi $(33,59 \pm 5,6 \%)$ daripada pengencer Tris Aminomethane kuning telur $+2 \%$ SKM $(24,69 \pm 4,5 \%)$ dan pengencer Tris
Aminomethane kuning telur $+0 \%$ $\operatorname{SKM}(22,62 \pm 4,53 \%)$.Hal ini menunjukkan bahwa perlakuan P2 memberikan pengaruh efektif dalam mempertahankan viabilitas spermatozoa sapi Limousin.

\section{Persentase abnormalitas spermatozoa dengan penambahan SKM}

Solihati dan Kune (2008) menyebutkan bahwa abnormalitas mengalami peningkatan setiap jam yang dipengaruhi oleh spermatogenesis dari ternak dan perlakuan semen setelah ejakulasi seperti penanganan semen segar, pencampuran semen dengan pengencer, pada saat pembuatan ulasan, dan lama waktu penyimpanan.

Hasil penelitian pada Tabel 4 menunjukkan bahwa rata-rata persentase abnormalitas spermatozoa sapi Limousin pada penyimpanan suhu $4-5^{\circ} \mathrm{C}$ tidak mengalami pengaruh nyata pada penyimpanan jam ke-2 sampai jam ke-72 (P>0,05). Hal ini menunjukkan bahwa abnormalitas spermatozoa sejalan dengan lama penyimpanan 
dimana selama penyimpanan 2-72 jam abnormalitas spermatozoa sapi Limousin mengalami fluktuasi pada berbagai konsentrasi sari kulit manggis. Pada penyimpanan jam ke-72 menunjukkan bahwa perlakuan penambahan SKM 4\% memiliki persentase abnormalitas yang lebih rendah jika dibandingkan dengan penambahan SKM 2\% dan perlakuan kontrol yaitu masing-masing P2 $(14,1 \pm 2,31 \%)$, P1 $(14,63 \pm 3,77 \%)$ dan P0 $(15,97 \pm 2,95 \%)$.

Tabel 4. Nilai rataan abnormalitas spermatozoa sapi Limousin terhadap perlakuan

\begin{tabular}{cccc}
\hline Jam ke- & P0 (0 \%) & P1 (2 \%) & P2 (4 \%) \\
\hline 1 & $9,91 \pm 3,19^{\mathrm{a}}$ & $8,15 \pm 2,12^{\mathrm{a}}$ & $7,04 \pm 0,89^{\mathrm{b}}$ \\
2 & $11,32 \pm 1,85$ & $10,02 \pm 3,99$ & $9,83 \pm 2,97$ \\
3 & $13,23 \pm 1,21$ & $12,04 \pm 3,35$ & $11,22 \pm 1,18$ \\
24 & $14,26 \pm 2,4$ & $14,14 \pm 4,9$ & $13,02 \pm 1,64$ \\
48 & $15,71 \pm 2,51$ & $14,45 \pm 4,86$ & $13,37 \pm 1,7$ \\
72 & $15,97 \pm 2,95$ & $14,63 \pm 3,77$ & $14,1 \pm 2,31$ \\
\hline
\end{tabular}

Keterangan : Notasi yang berbeda pada baris yang sama menunjukan berbeda nyata $(\mathrm{P}<0,05$

Abnormalitas setelah pendinginan pada suhu $5^{\circ} \mathrm{C}$ selama penyimpanan jam ke-72 masih menunjukkan angka di bawah $20 \%$ pada semua perlakuan, sehingga masih layak digunakan untuk inseminasi buatan. Parera, dkk.(2009) menyebutkan bahwa angka morfologi abnormal $8-10 \%$ tidak memberikan pengaruh yang cukup berarti bagi fertilitas, tetapi jika abnormalitas lebih dari $25 \%$ per ejakulat maka penurunan fertilitas tidak dapat diantisipasi. Ihsan (2008) menjelaskan bahwa pendinginan menyebabkan peningkatan abnormalitas dan kerusakan sel namun masih dapat teratasi dengan adanya pengencer yang mengandung kuning telur yang didalamnya mengandung lesitin dan lipoprotein.Kedua zat tersebut berfungsi mempertahankan integritas selubung lipoprotein dari sel dan mencegah cekaman dingin.

Persentase abnormalitas spermatozoa pada penyimpanan jam ke1 mengalami perbedaan yang nyata $(\mathrm{P}<0,05) \quad$ karena proses adaptasi spermatozoa terhadap lingkungan baru yaitu dengan pengencer Tris
Aminomethane kuning telur + persentase SKM sesuai perlakuan kurang dari 1 jam sehingga belum menunjukkan perkembangan yang signifikan. Kandungan tannin pada sari kulit manggis juga menyebabkan membran sel spermatozoa mempertahankan

intraselulernya.Smullen, et al(2007) menyebutkan bahwa kandungan tanin dalam kulit manggis merupakan basis aktivitas antibakteri dengan merusak membran sel yang menyebabkan kebocoran intraselular.Akibat terganggunya permeabilitas dan rusaknya fungsi integritas membran sitoplasma, sel tidak dapat melakukan aktivitas hidup sehingga pertumbuhannya terhambat atau bahkan mati. Pada lama penyimpanan 72 jam, abnormalitas spermatozoa paling rendah diperoleh pada level sari kulit manggis $4 \%$,yakni sebesar $14,10 \%$ atau masih dalam kategori normal. Nugroho dkk. (2015) menjelaskan bahwa rataan nilai abnormalitas semen segar sapi Limousin yang masih tergolong baik berkisar 5-15\%. 


\section{KESIMPULAN DAN SARAN}

Pengencer Tris Aminomethane kuning telur dengan penambahan 0,2 dan 4\% SKM mampu mempertahankan kualitas semen Sapi Limousin yangdisimpan pada suhu dingin $5^{\circ} \mathrm{C}$ selama 72 jammeliputi konsentrasi, motilitas, viabilitas dan abnormalitas. Pengencer Tris Aminomethane kuning telur $+4 \%$ SKM menunjukkan persentase motilitas, viabilitas dan abnormalitas yang terbaik. Penelitian ini menggunakan semen segar afkir dengan persentase motilitas $\leq 70 \%$ sehinggamemerlukan studi lebih lanjut dengan menggunakan semen segar yang memiliki motilitas awal sesuai standar SNI yaitu $\geq 70 \%$ sehingga dapat diketahui waktu penyimpanan optimum.

\section{DAFTAR PUSTAKA}

Arsana, I. N. 2014. Ekstrak kulit buah Manggis (Garcinia mangostana L.) dan pelatihan fisik menurunkan stres oksidatif pada tikus Wistar (Rattus norvegicus) selama aktivitas fisik maksimal. Disertasi. Denpasar: Universitas Udayana: 1-27.

Ax, R., M. Dally, B. A. Didion, W. Lenz, C. Love, D. Varner, B. Hafez and M. E. Bellin, 2008. Artificial insemination in B. Hafez and E. S. E. Hafez. Reproduction in Farm Animals. $7^{\text {th }}$ Ed. Lippincott Williams \& Wilkins. Baltimore, Marryland, USA.

Brito, L., F. Silva, L. Rodrigues, F. Vieira, G. Deragon, J. P. and Kastelic. 2002. Effect of Environmental Factors, Age and Genotype on Sperm Production and Semen Quality in Bos indicus and Bos taurus AI Bulls in Brazil. Animal Reproduction Science. 70 (2): 181-190.
Caridi, D., V. C. Trenerry, S. Rochfort, S. Duong, D. Laugher and R. Jones. 2007. Profiling and quantifying quercetin glucosides in Garcinia mangostanavarieties using cappilary zone electrophoresis and high performance liquid chromatography. Food Chemistry. 105 (4): 691-699.

Chaovanalikit, A., A. Mingmuang and T. Kitbunluewit. 2012. Anthocyanin and total phenolics content of Mangosteen and effect of processing on the quality of Mangosteen products.

International Food Research Journal. 19 (3): 1047-1053. Faculty of Agricultural Product Innovation and Technology. Srinakharinwirot Univerisity. Thailand.

Garner, D. L. and E. S. E. Hafez. 2008. Spermatozoa and seminal plasma. In B. Hafez dan E.S.E. Hafez. Reproduction in farm animal $7^{\text {th }}$ ED. Lippinicot Williams and Wilkins Baltimore, Marryland, USA.

Ihsan, M. N. 2008. Upaya peningkatan konsentrasi spermatozoa hasil pemisahan dengan sentrifugasi gradien densitas Percoll pada Sapi Friesian Holstein (FH). Disertasi. Program Pascasarjana Fakultas Pertanian Universitas Brawijaya Malang.

Ismaya. 2014. Bioteknologi inseminasi buatan pada sapi dan kerbau. Gadjah Mada University Press: Yogyakarta.

Jung, H. A., Su, B. N. Keller, W. J. Metha and A. D. Kinghorn. 2006. Antioxidant xanthones from the pericarp of Garcinia mangostana (Mangosteen). J. Agric. Food Chem. 54 (1): 2077-82. 
Lopes, F.P. 2002. Semen collection and evaluation in ram. ANS 33161. University of Florida.

Nugroho, Y., T. Susilawati, dan S. Wahjuningsih. 2015. Kualitas semen Sapi Limousin selama pendinginan menggunakan pengencer CEP-2 dengan penambahan berbagai konsentrasi kuning telur dan sari buah jambu biji (Psidium guajava). J. Ternak Tropika. 15 (1): 31-42.

Parera, F., Z. Prihatiny, D.F. Souhoka, dan M. Rizal. 2009. Pemanfaatan sari wortel sebagai pengencer alternatif spermatozoa epididimis Sapi Bali. J. Indon. Trop. Anim. Agric. 34(1): 50-56.

Sikka, S. C. 2004. Role of oxidative stress and antioxidants in andrology and assisted reproductive technology. Journal Androl. 25 (2): 5-18.

Smullen, J., Koutsou, G. A., Foster, H. A., A. Zumbe and D. M. Storey. 2007. The Antibacterial activity of plant extracts containing polyphenols against Streptococcus mutans, Caries Res. 41 (2): 342349.

Solihati, N dan P. Kune. 2008. Studi terhadap kualitas dan daya tahan hidup spermatozoa cauda epididimis domba Garut menggunakan berbagai jenis pengencer. Seminar nasional teknologi peternakan dan veteriner.

Susilawati, T., S. B. Sumitro, S. Hardjoprantoro, M. S. Djati dan G. Ciptadi 2008. Kaji banding antara pengencer tris dengan TCM-199 dalam upaya pembekuan semen sapi hasil penyaringan Sephandex G-200. Media Veteriner. 6 (4): 9-13.

Susilawati, T. 2011. Spermatology. UB Press. Universitas Brawijaya. Malang.

Suyadi, A. Rachmawati dan N. Iswanto. 2012. Pengaruh $\alpha$-tocopherol yang berbeda dalam pengencer dasar tris aminomethane-kuning telur terhadap kualitas semen Kambing Boer yang disimpan pada suhu 5 ${ }^{\circ} \mathrm{C}$. Jurnal Ilmu-Ilmu Peternakan. 22 (3): 1-8.

Wahjuningsih, A., D .M. Saleh, dan Sugiyatno. 2013. Pengaruh umur pejantan dan frekuensi penampungan terhadap volume dan motilitas semen segar Sapi Simmental di Balai Inseminasi Buatan Lembang. Jurnal Ilmiah Peternakan 1 (3): 947-953.

Wiratri, V. D. B., T. Susilawati dan S. Wahjuningsih. 2014. Kualitas semen Sapi Limousin pada pengencer yang berbeda selama pendinginan. J. Ternak Tropika. 15 (1): 13-20.

Zaniboni, L., R. Rizzi and S. Cerolini. 2006. Combined effect of DHA and $\alpha$-tocopherol enrichment on sperm quality and fertility in the Turkey. Theriogenology. 65 (1): 1813-1827.

Zega, I., S. Ilyas dan S. Hutahaean. 2015. Kualitas spermatozoa Sapi Limousin dalam pengencer twostetm extender dengan suplementasi kuning telur bebek selama penyimpanan pada refrigerator. Jurnal Biosains. 1 (3): 66-72. 